\title{
Catalytic Polymerization of Butadiene in Aqueous Systems with Cationic Nickel(II) Complexes
}

\author{
Brigitte Korthals, Andreas Berkefeld, Martin Ahlmann, and Stefan Mecking* \\ Universität Konstanz, Lehrstuhl für Chemische Materialwissenschaft, Fachbereich Chemie, \\ Universitätsstrasse 10, D-78457 Konstanz, Germany
}

\begin{abstract}
The cationic nickel(II) complexes $\left[\left(\eta^{3}-\mathrm{C}_{3} \mathrm{H}_{5}\right) \mathrm{Ni}\left(\mathrm{SbPh}_{3}\right)_{2}\right]\left[\mathrm{B}\left(3,5-\left(\mathrm{CF}_{3}\right)_{2} \mathrm{C}_{6} \mathrm{H}_{3}\right)_{4}\right]$ (2) and $\left[\left(\eta^{3}-\right.\right.$ $\left.\left.\mathrm{C}_{3} \mathrm{H}_{5}\right) \mathrm{Ni}\left(\mathrm{SbPh}_{3}\right)_{2}\right]\left[\mathrm{Al}\left(\mathrm{OC}\left(\mathrm{CF}_{3}\right)_{3}\right)_{4}\right](3)$ were prepared and their polymerization activities in aqueous systems were compared with $\left[\left(\eta^{3}-\mathrm{C}_{3} \mathrm{H}_{5}\right) \mathrm{Ni}\left(\eta^{6}-\mathrm{BHT}\right)\right]\left[\mathrm{B}\left(3,5-\left(\mathrm{CF}_{3}\right)_{2} \mathrm{C}_{6} \mathrm{H}_{3}\right)_{4}\right](\mathbf{1})(\mathrm{BHT}=3,5$-di-tert-butyl-4-hydroxytoluene $)$. Cispolybutadiene is formed in nonaqueous solution polymerization. The presence of water decreases activity and polymer molecular weight and increases trans incorporation of butadiene units. In emulsion polymerization, stable polymer dispersions can be obtained with complex $\mathbf{2}$ and $\mathbf{3}$, respectively. The microstructure is strongly altered by comparison to nonaqueous polymerization. Trans-polybutadiene is formed with activities of up to $1.5 \times 10^{3}$ mol (butadiene) mol $(\mathrm{Ni})^{-1} \mathrm{~h}^{-1}$. The semicrystalline latex particles have sizes of ca. $200 \mathrm{~nm}$, with a monoclinic structure.
\end{abstract}

\section{Introduction}

Emulsion and suspension polymerization are widely applied on an industrial scale. Water as a continuous phase is beneficial due to its high heat capacity, and its nonflammability and nontoxicity. In addition to these process advantages, polymerization in aqueous emulsion can give access to polymer latices, which are used e.g. in environmentally friendly coatings and paints. ${ }^{1}$

Butadiene is an attractive monomer conveniently available from steam cracking. It can be incorporated in different fashions (1,2 or vinylic incorporation, 1,4-cis and 1,4-trans incorporation) which gives access to a wide variety of different polymer microstructures differing in crystallinity and thermal properties. Latices of polybutadiene are accessible via free-radical emulsion polymerization, however the microstructure is difficult to control (a typical microstructure is 14\% 1,4-cis; 69\% 1,4-trans; and $17 \% 1,2)$, and cross-linking and gel formation can occur. ${ }^{2}$

Transition-metal catalyzed polymerization can provide access to a broader scope of microstructures. Nonaqueous solution polymerization is employed industrially on a large scale for the preparation of 1,4-cis polybutadiene. ${ }^{2}$ An early report describes the use of rhodium salts for the synthesis of 1,4-transpolybutadiene in water or other polar solvents, however the yields are very low and dispersions are not obtained. The nature of the catalyst has remained unclear. ${ }^{3}$ Neutral cobalt complexes $\left[\mathrm{Co}\left(\mathrm{C}_{8} \mathrm{H}_{13}\right)\left(\mathrm{C}_{4} \mathrm{H}_{6}\right)\right]^{4}$ in combination with $\mathrm{CS}_{2}$ afford dispersions of syndiotactic 1,2-polybutadiene, using mini- or microemulsion techniques. ${ }^{5}$ By ring-opening metathesis polymerization (ROMP) with (neutral) ruthenium alkylidenes as catalyst precursors 1,4polybutadiene latices can be obtained, however 1,5-cyclooctadiene is required as a monomer. ${ }^{6}$

Cationic nickel(II) complexes are well-known to be highly active for the polymerization of butadiene. ${ }^{7} 1,2$ incorporation is low (around 5\%) and the ratio between cis and trans incorporation depends on the nature of the ligands and counteranions. However, cationic organometallic complexes are generally more prone to undesired reactions with water due to their increased electrophilicity by comparison to their neutral counterparts. Thus, studies of catalytic polymerization in aqueous systems in general have relied on neutral catalysts. ${ }^{8}$

We now report on studies of polymerization with cationic $\mathrm{Ni}(\mathrm{II})$ complexes in aqueous systems.

\footnotetext{
* Corresponding author. E-mail: stefan.mecking@uni-konstanz.de.
}

\section{Results and Discussion}

Complexes. Complex 1 and analogs of $\mathbf{2}$ with other counterions are known to polymerize butadiene and other dienes with a high activity in organic solvents. ${ }^{7,9}$ For a complex $\left[\left(\eta^{3}-\right.\right.$ $\left.\left.\mathrm{C}_{3} \mathrm{H}_{5}\right) \mathrm{NiL}_{2}\right]^{+} \mathrm{A}^{-}$as a catalyst precursor, formation of the polymerization-active species requires that sites for the coordination of monomer are provided by dissociation of $\mathrm{L}^{7}$ Complexes 1, 2 and 3, respectively, all contain relatively weakly binding ligands L, a single $\eta^{6}$-coordinating arene in $\mathbf{1}$ and two monodentate $\mathrm{SbPh}_{3}$ ligands in 2 and 3. The noncoordinating $\mathrm{BAr}_{4}{ }^{-}\left(\mathrm{Ar}^{\mathrm{F}}=3,5-\left(\mathrm{CF}_{3}\right)_{2} \mathrm{C}_{6} \mathrm{H}_{3}\right)$ counterion provides solubility in organic solvents. The $\mathrm{Al}\left(\mathrm{OC}\left(\mathrm{CF}_{3}\right)_{3}\right)_{4}{ }^{-}$anion has been suggested recently as an alternative to commonly used borate anions. ${ }^{10}$

Complex 1, with BHT (BHT = 3,5-di-tert-butyl-4-hydroxytoluene) as a $\eta^{6}$-ligand, was prepared according to a known procedure. ${ }^{9}$ Analogs of complex $\mathbf{2}$ and $\mathbf{3}$ with the weakly coordinating counterions $\mathrm{PF}_{6}^{-}$and $\mathrm{BF}_{4}{ }^{-}$have been reported previously. ${ }^{11}$ One of the synthesis procedures reported already suggests some stability of the cation toward water: a solution of the presumably intermediately formed $\left[\left(\eta^{3}-\mathrm{C}_{3} \mathrm{H}_{5}\right) \mathrm{Ni}\right.$ $\left.\left(\mathrm{SbPh}_{3}\right)_{2}\right] \mathrm{X}\left(\mathrm{X}^{-}=\right.$halide $)$exchanges its anion with an aqueous $\mathrm{NaPF}_{6}$ solution. However, the contact to water was minimized as the product $\left[\left(\eta^{3}-\mathrm{C}_{3} \mathrm{H}_{5}\right) \mathrm{Ni}\left(\mathrm{SbPh}_{3}\right)_{2}\right] \mathrm{PF}_{6}$ immediately precipitated. 2 and 3 were obtained by reaction of $\left[\left\{\left(\eta^{3}-\mathrm{C}_{3} \mathrm{H}_{5}\right) \mathrm{NiCl}\right\}_{2}\right]$ with $\mathrm{SbPh}_{3}$ and $\mathrm{NaBAr}_{4}{ }_{4}$, or $\mathrm{Li}\left[\mathrm{Al}\left(\mathrm{OC}\left(\mathrm{CF}_{3}\right)_{3}\right)_{4}\right]$ respectively, in diethyl ether.

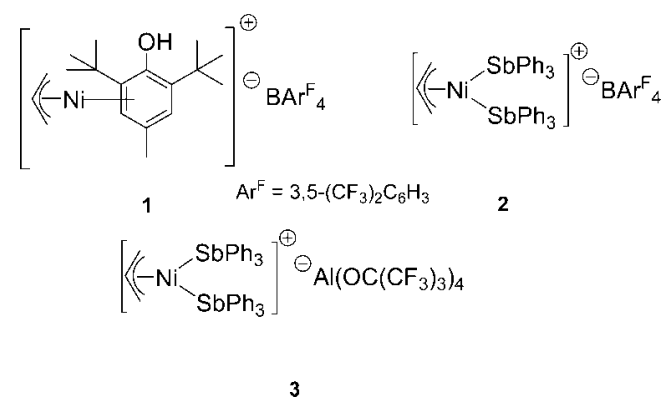

The molecular structure of $\mathbf{3}$ was determined by single crystal $\mathrm{X}$-ray crystallography (Figure 1). ${ }^{12}$ The coordination environment of the $\mathrm{Ni}$ (II) center is symmetrical as expected, with $\mathrm{Ni}-\mathrm{C} 12.0501$ (0.0055) $\mathrm{A}, \mathrm{Ni}-\mathrm{C} 32.0325$ (0.0062) $\mathrm{A}$, and $\mathrm{Ni}-\mathrm{Sb} 12.4617$ (0.0007) $\AA$, Ni-Sb2 2.4599 (0.0007) $\AA$ 


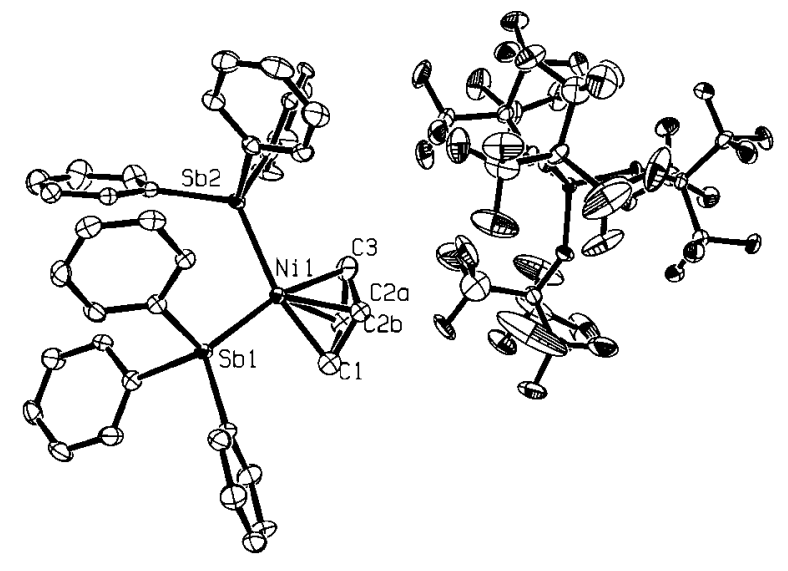

Figure 1. X-ray diffraction analysis of complex 3 (50\% ellipsoids, $\mathrm{H}$-atoms omitted for clarity). The solid-state structure is disordered with C2 occupying two split positions.

$\left(\mathrm{Sb} 1-\mathrm{Ni}-\mathrm{Sb} 2103.23(0.03)^{\circ}\right)$. The central carbon atom of the allylic moiety was found to be disorderd $(\mathrm{Ni}-\mathrm{C} 2 \mathrm{a} 2.0205$ (0.0096) $\AA$ and Ni-C2b 2.0099 (0.0154) $\AA$ with 60\% C2a and $40 \% \mathrm{C} 2 \mathrm{~b}$ ). No strong cation-anion interaction is evident from the structure in the solid state.

${ }^{1} \mathbf{H}$ NMR Studies. NMR studies were carried out in order to survey the reactivity of $\mathbf{1}$ and $\mathbf{2}$ toward water. Exposure of $\mathbf{1}$ to 10 equivalents of water in $\mathrm{CD}_{2} \mathrm{Cl}_{2}$ solution at room temperature results in decomposition within minutes, to form a black solid and the free arene. ${ }^{13}$

Complex 2 stays intact under identical conditions. The ${ }^{1} \mathrm{H}$ NMR signals, including those of the characteristic allylic system, remain unaltered. Also macroscopically no change is observed, the solution remains colored intensely red, and no precipitate is formed. Interestingly, the reactivity of $\mathbf{2}$ toward butadiene is different in the absence and in the presence of traces of water (Figure 2). In both cases, addition of butadiene results in an immediate change of the signals of the $\mathrm{SbPh}_{3}$ ligand and the disappearance of the allylic signals of 2 . Presumably, displacement by the monomer (and/or the unsaturated moieties in the growing polymer chain) occurs. In the absence of water, 2 rapidly polymerizes butadiene to 1,4-cis-polybutadiene, as expected for $\mathrm{Ni}$ (II) complexes with weakly coordinating ligands and anions. ${ }^{7}$ Polymerization is also observed immediately in the presence of water after the addition of butadiene, but at a lower rate. Strikingly, the polymer formed largely consists of 1,4-trans repeat units, as evidenced by the different shape of the signals of both the methylene and methine protons (Figure 2).

Butadiene can coordinate in two different modes forming an anti and a syn-butenylnickel(II) complex (cf. Scheme 1). The cis-trans selectivity depends kinetically on the reactivity of these complexes and thermodynamically on the concentration of both. In general, a higher trans selectivity is accompanied with a decrease in activity. ${ }^{7}$ A strongly coordinating ligand can shift the selectivity toward trans. A possible explanation for the preference for trans-incorporation in the presence of water is coordination of water to the active species.

Solution Polymerizations. Polymerization activities observed with $\mathbf{2}$ and $\mathbf{3}$ as catalyst precursors in dry solvents (entries 1-4 and 1-7 in Table 1) are comparable to activities reported for analogous $\mathrm{SbPh}_{3}$ complexes with other noncoordinating counterions under similar conditions. ${ }^{11}$ The activity of $\mathbf{2}$ is lower in the presence of added water, and a higher trans incorporation is observed. Polymer analysis revealed that the degree of trans incorporation correlates with the solubility of water in the organic solvent utilized (entries 1-5 and 1-8) (solubility of water in toluene $0.06 \mathrm{wt} \%$, in methylene chloride $1.6 \mathrm{wt} \%$ at $\left.30{ }^{\circ} \mathrm{C}\right) .{ }^{14}$ An increase of the polymerization time from the standard $30 \mathrm{~min}$ to $4 \mathrm{~h}$ in the presence of water (entries 1-5 and $1-6)$ resulted in a similar conversion and overall catalyst productivity in terms of monomer converted per metal center present in the reaction mixture as in the absence of water (entry $1-4)$. That is, the polymerization is slower in the presence of water, but the catalyst remains intact at least partially over prolonged time under these conditions.

Under water-free conditions the catalyst formed from complex $\mathbf{1}$ is somewhat more active than $\mathbf{2}$, as previously reported (entry $1-1) .{ }^{9}$ The polymerization proceeded with a strong exotherm, the temperature rising by $25^{\circ} \mathrm{C}$ within minutes despite cooling of the reactor. In this case, the observed catalyst activity is limited by the complete consumption of butadiene. The effect of water on the polymerization with $\mathbf{1}$ is more pronounced than with $\mathbf{2}$. When water is added to $\mathbf{1}$ directly before starting of the polymerization (entry $1-2$ ) a limited conversion of butadiene is observed. This is likely due to a decomposition of this catalyst precursor by water, as observed in the aforementioned NMR studies. Accordingly, exposure of $\mathbf{1}$ to water for $15 \mathrm{~min}$ prior to polymerization results in a further lowering of butadiene conversion (entry 1-3).

Suspension Polymerization. A certain degree of stability of the catalyst toward water is a prerequisite for polymerizations in disperse aqueous systems such as suspension polymerization. This can be realized by a nonaqueous prepolymerization followed by the actual suspension polymerization. $\mathbf{1}$ or $\mathbf{2}$ were dissolved in a small amount of a mixture of methylene chloride and toluene, which is a solvent for the complex as well as for the polymer formed in the next step. A small amount of butadiene was added, resulting in polymerization (cf. Table 2 for details). After this prepolymerization in the absence of water, water and further butadiene were added, and the mixture was stirred vigorously. Polymerization continues, with rates and conversions comparable to solution polymerizations in the absence of water (Table 2, entries $2-1$ and $2-2$, vs $1-1,1-4$ and $1-7)$. The hydrophobic polymer formed in the prepolymerization appears to hinder the access of water to the active species to a certain extent. As in the aforementioned solution polymerizations with added water, a slightly higher trans incorporation is observed by comparison to polymerizations in the absence of water.

Due to the high heat capacity of water, the reaction temperature can be controlled well, also a low viscosity of the reaction mixture can be maintained. When stirring is stopped at the end of the suspension polymerization the highly viscous, liquid polymer phase readily separates from the aqueous phase. For all polymers obtained from the solution and suspension polymerizations a glass transition temperature around $-100{ }^{\circ} \mathrm{C}$ is observed in DSC, as expected for polybutadienes with a high 1,4-cis content.

Emulsion Polymerization with Prepolymerization. Most commonly surfactants, which are physically bound to the polymer particle surface, are employed in emulsion polymerization to colloidally stabilize the polymer particles formed. To probe for any conceivable unfavorable interaction of surfactants with the cationic catalyst, SDS surfactant was added with the aqueous phase under conditions otherwise identical to the aforementioned suspension polymerization with 1 (entry 2-3). Butadiene polymerization proceeded, but the conversion was significantly lower than in the absence of surfactant, despite a longer reaction time. As expected, the polymer is formed as a colloidally instable macroemulsion, which exhibits strong skimming after stopping of the stirrer. A direct interaction of the cationic nickel center and the surfactant anion appears unlikely as the reason for the lower activity. The experiment was repeated 

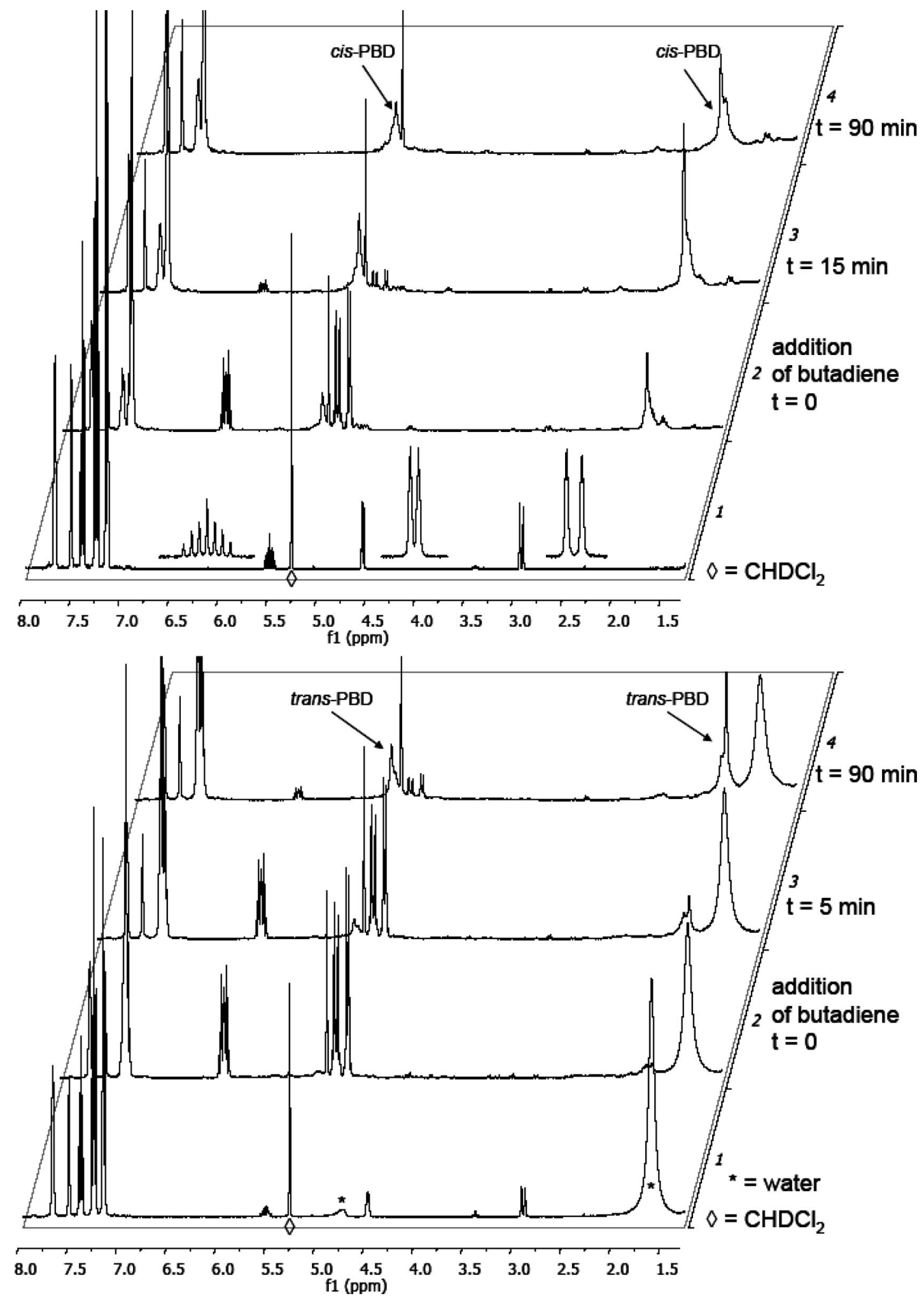

Figure 2. Reactivity of complex 2 toward butadiene in the absence (top) and in the presence (bottom) of water $\left(500 \mu \mathrm{L} \mathrm{CD} \mathrm{Cl}_{2} ; 25{ }^{\circ} \mathrm{C}\right.$; initial concentrations of [2] ca. $40 \mathrm{mmol} \mathrm{L}^{-1}$; [butadiene] ca. $240 \mathrm{mmol} \mathrm{L}^{-1}$ ).

with other surfactants including nonionic surfactants (Dowfax, Lutensol, Plantacare), but in all cases the catalyst productivity and monomer conversion was equal to or even lower than with SDS.

To obtain a polymer latex, a high degree of dispersion of the catalyst in the initial polymerization mixture is a prerequisite. ${ }^{15}$ This can be realized for the lipophilic catalyst precursors studied by miniemulsification of the solution obtained from prepolymerization in the absence of water. The latter solution was ultrasonicated with an aqueous SDS solution and additional butadiene (entry 2-4). No further butadiene polymerization appears to occur in the emulsion obtained. As a product a stable latex was obtained, however this is a secondary dispersion of the polymer formed during the nonaqueous prepolymerization rather than an emulsion polymer. Creation of a large interface between organic and aqueous phase and the intimate mixing during sonication likely result in catalyst decomposition by water. 


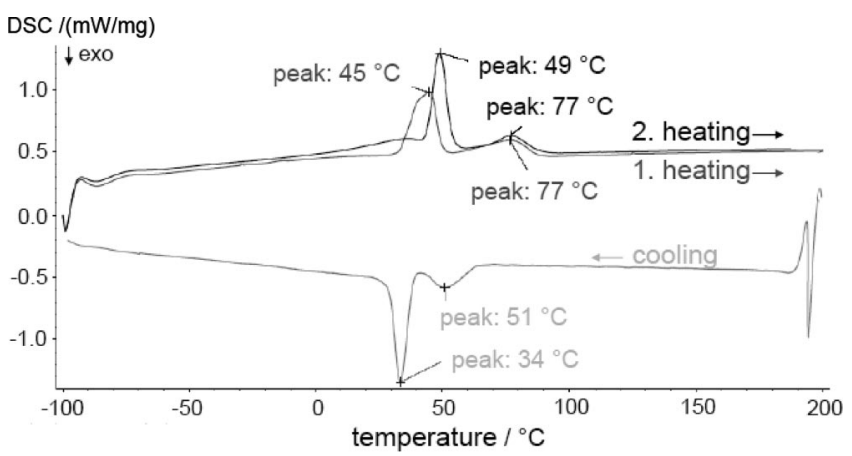

Figure 3. Differential scanning calorimetry of 1,4-trans-polybutadiene synthesized via emulsion polymerization without prepolymerization (entry 3-6).

Emulsion Polymerization without Prepolymerization. In accordance with these considerations, a similar procedure without nonaqueous prepolymerization, namely miniemulsification by ultrasonication of mixture of a solution of $\mathbf{2}$ in methylene chloride, butadiene, and an aqueous SDS solution resulted in the formation of traces of polymer only. When an analogous procedure was conducted with pentane, in which 2 is completely insoluble, instead of methylene chloride, substantial amounts of polymer were obtained indeed, however in the form of coagulate.

Stable polybutadiene latices could be obtained by fine-tuning the conditions such that the precatalyst is only slightly soluble, and dissolved only to a small part in the initial mixture (Table 3 ). Mixing of complex $\mathbf{2}$ with a small amount of toluene insufficient for complete dissolution of $\mathbf{2}$ resulted in a dark red solution with a yellow solid. Upon stirring vigorously with excess water the red color remains, indicating the presence of intact complex. This is also the case after miniemulsification, and discoloring only occurs after polymerization upon releasing residual butadiene pressure and exposure to air.

A possible explanation is that the insolubility of the catalyst precursor, which results in a low reactivity, largely prevents decomposition during the miniemulsification step. The active species (cf. Scheme 1) may be more prone toward decomposition by water, particularly during the vigorous mixing conditions of miniemulsification, than 2. Dissolution of the catalyst precursor to the active $\mathrm{Ni}$ - polymeryl species occurs relatively slowly and only after the miniemulsification step, in the organic droplets generated. The solubility of the precatalyst needs to be balanced subtly, as complete insolubility results in colloidal instability of the product reaction mixture as outlined. The importance of catalyst solubility is underlined by polymerization experiments conducted with 3 . The $\mathrm{Al}\left(\mathrm{OC}\left(\mathrm{CF}_{3}\right)_{3}\right)_{4}{ }^{-}$anion provides a higher solubility in toluene. Accordingly, polymer yields under identical conditions are significantly lower.

The polymer from all emulsion polymerizations with partly dissolved $\mathbf{2}$ or $\mathbf{3}$ is formed as a stable dispersion, only samples with the highest solids content exhibited a very slight skimming. Remarkably, the polymers formed contain 1,4-trans repeat units predominantly (Table 3 ). The high degree of dispersion present in the emulsion system appears to promote interaction of the catalyst with water to such an extent that the microstructure is entirely altered. A conceivable radical polymerization mechanism appears unlikely as 1,2 incorporation remains much lower (4\%) than would be expected for a radical polymerization. ${ }^{2}$ Indeed, comparative free-radical emulsion polymerizations of butadiene (e.g., 25 or $50{ }^{\circ} \mathrm{C}$; initiator WAKO VA-044 = 2,2'azobis[2-(2-imidazolin-2-yl)propane]dihydrochloride; SDS surfactant) and analysis of the polymer formed in our hands afforded a 1,2-content of $21 \%$ and $17 \%$ respectively (for selected IR spectra see Supporting Information). Catalytic emulsion polymerization also occurred in the presence of 2 equiv of BHT radical inhibitor. The microstructure is unaffected by the presence of BHT $(4 \%$ 1,2). As expected, polymerization rate is reduced (ca. 5-fold) as BHT can coordinate to the $\mathrm{Ni}^{\mathrm{II}}$ center (cf. complex 1).

As stated previously, the turnover frequency for catalytic 1,4trans polymerization with cationic nickel(II) complexes tends to be much lower than for 1,4-cis polymerization. The system studied is among the most active reported to date for trans polymerization. ${ }^{7}$ Number average molecular weights of the polybutadienes obtained are several $10^{4} \mathrm{~g} \mathrm{~mol}^{-1}$.

The catalyst remains active for at least $30 \mathrm{~min}$ (entry $3-2 \mathrm{vs}$ 3-3; and entry 3-7). Overall catalyst productivity and polymer yields were higher (entries 3-4 to 3-7), when the reaction was performed on a larger scale of $300 \mathrm{~mL}$ and with a correspondingly increased amount of catalyst and monomer.

Complex 1 was deactivated under similar conditions due to its higher sensitivity to water.

Polymer Properties. The high trans content results in a semicrystalline solid polymer. 1,4-trans polybutadiene is known to exist in a monoclinic form at room temperature and to undergo a crystal to crystal transition at elevated temperature to form a hexagonal form, which subsequently melts. ${ }^{16}$ The equilibrium phase transition temperature was calculated to be $83{ }^{\circ} \mathrm{C}$ for $100 \%$ 1,4-trans polybutadiene, and the equilibrium melting temperature to be $164{ }^{\circ} \mathrm{C} .{ }^{17}$ In differential scanning calorimetry (DSC) the polymers from polymerization in emulsion show an endothermic peak ranging between 47 and $49^{\circ} \mathrm{C}$ which can be associated with the change of the unit cell, and a broader endothermic peak between 70 and $80^{\circ} \mathrm{C}$ when melting occurs. It is well-known for 1,4-trans polybutadiene, that the phase transition temperature depends not only on the stereoerrors but that there is a strong influence of the thickness of the lamellae. More than one phase transition temperature can be observed if the polymer consists of lamellae of different thickness. It is evident from the first heating trace that the polymer is generated in emulsion in the monoclinic form. However, the endothermic peak is slightly broader than in the second heating which could be assigned to lamellae of different thickness. The melting temperature is lower by comparison to the calculated equilibrium melting temperature of 1,4-transpolybutadiene due to the presence of cis and 1,2-repeat units.

The stable, opaque white polybutadiene latices contain particles of around $200 \mathrm{~nm}$ size, as observed by TEM (Figure 4). The particles are not featureless but appear to consist of several staggered layers. This is thought to originate from the crystalline nature of the polymer as 1,4-trans polybutadiene crystallizes in lamellae.

Electron diffraction (ED) analysis of a latex particle affirms the crystalline nature (Figure 5). It has been shown that under the radiation of electron beam during the ED investigation of 1,4-PBD the phase transition from the monoclinic to the hexagonal crystal form occurs. ${ }^{18}$ As a consequence usually a coexistence of both ED patterns is observed. In order to delay the phase transition process and minimize the damage of the electron beam to the packing order of the crystal, the sample was cooled down to $-64{ }^{\circ} \mathrm{C}$ using a cryo sample holder and the TEM was directly set to the selected-area electron diffraction mode. Figure 5 shows the ED pattern from a single crystal or some lamellae with the same orientation corresponding to the (001) zone of a monoclinic crystal with the spots from (200), (120) and (040) planes.

\section{Summary and Conclusions}

Catalytic polymerizations can be carried out in disperse aqueous systems with cationic Ni(II) complexes. Polybutadienes with number average molecular weights of typically $3 \times 10^{4} \mathrm{~g}$ 
Scheme 1. Simplified Mechanistic Scheme for the 1,4-Polymerization of Butadiene with Cationic Allylnickel(II) Complexes According to Taube $^{7}$

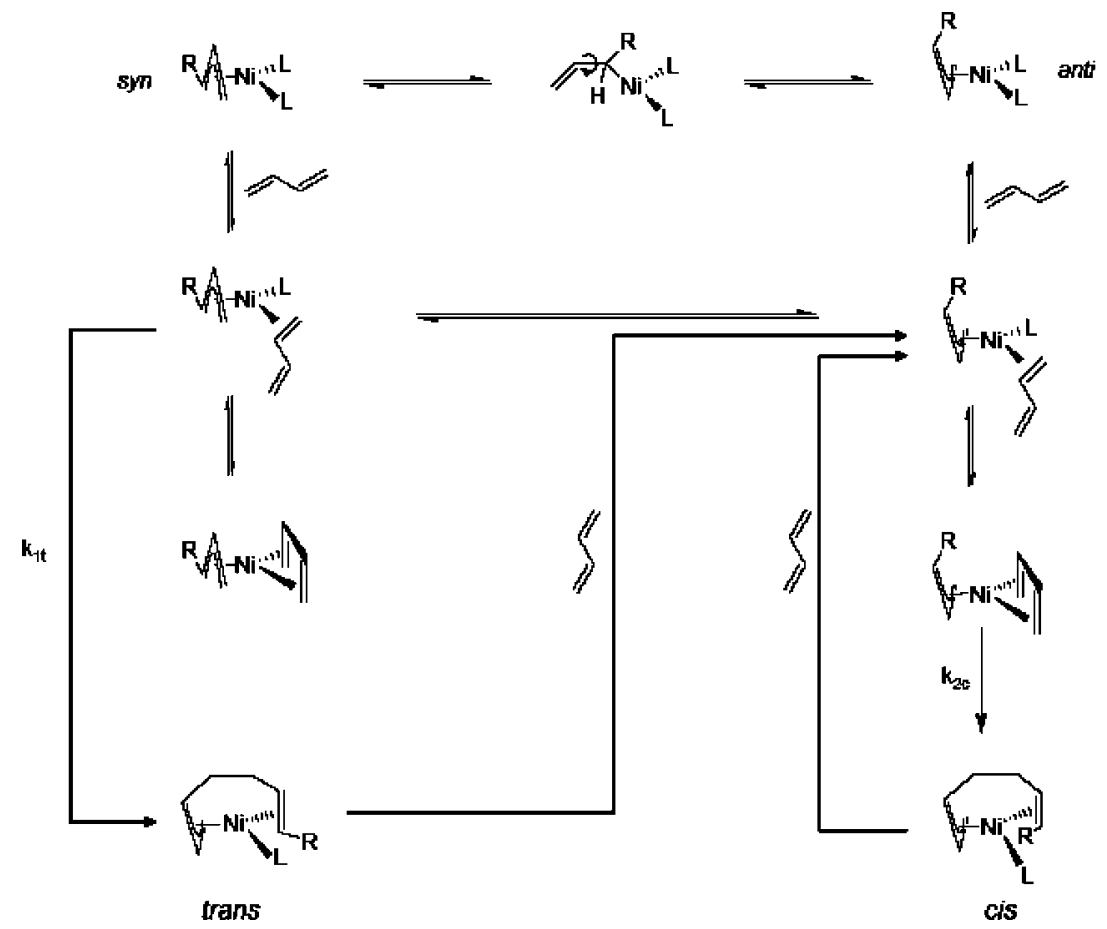

Table 1. Solution Polymerization ${ }^{a}$ of Butadiene with 1,2 and 3

\begin{tabular}{|c|c|c|c|c|c|c|c|}
\hline no. & complex $(\mu \mathrm{mol})$ & solvent & $\mathrm{BD}[\mathrm{g}]$ & $\mathrm{PBD}^{b}[\mathrm{~g}]($ yield [\%]) & $\mathrm{TON}[\mathrm{mol}(\mathrm{BD}) / \mathrm{mol}(\mathrm{Ni})]$ & $\begin{array}{l}\mathrm{M}_{\mathrm{n}}\left(\mathrm{M}_{\mathrm{w}} / \mathrm{M}_{\mathrm{n}}\right)^{c} \\
{\left[10^{3} \mathrm{~g} \mathrm{~mol}^{-1}\right]}\end{array}$ & vinyl/trans $/$ cis $^{d}$ \\
\hline $1-1$ & $1(25)$ & toluene & 15 & $15.0(100)$ & $1.1 \times 10^{4}$ & $34(4.4)$ & $4 / 4 / 92$ \\
\hline $1-2$ & $1(25)$ & toluene + water $^{e}$ & 15 & $4.2(28)$ & $3.1 \times 10^{3}$ & $11(1.8)$ & $4 / 7 / 89$ \\
\hline $1-4$ & $2(25)$ & toluene & 13 & $10.3(79)$ & $7.6 \times 10^{3}$ & $31(3.0)$ & $4 / 3 / 93$ \\
\hline $1-5$ & $2(25)$ & toluene + water $^{e}$ & 16 & $5.8(36)$ & $4.3 \times 10^{3}$ & $12(2.0)$ & $4 / 6 / 89$ \\
\hline $1-6$ & $2(25)$ & toluene + water $^{e}$ & 15 & $9.7(66)$ & $7.2 \times 10^{3}$ & $8.0(2.2)$ & $4 / 8 / 88$ \\
\hline $1-7$ & $2(25)$ & $\mathrm{CH}_{2} \mathrm{Cl}_{2}$ & 11 & $7.8(71)$ & $5.8 \times 10^{3}$ & $12(2.5)$ & $4 / 3 / 93$ \\
\hline
\end{tabular}

${ }^{a}$ Reaction conditions and procedure: $\mathbf{1}, \mathbf{2}$ or 3, respectively, dissolved in $100 \mathrm{~mL}$ of the organic solvent, where applicable addition of approximately 2 $\mathrm{mL}$ of water, addition of butadiene, polymerization for $30 \mathrm{~min}(4 \mathrm{~h}$ for entry $1-6)$ at $25^{\circ} \mathrm{C} .{ }^{b}$ Isolated by precipitation with methanol. ${ }^{c}$ Determined by GPC vs PS standards. ${ }^{d}$ Determined by IR. ${ }^{e}$ Addition of $2 \mathrm{~mL}$ of water directly before polymerization. ${ }^{f}$ Addition of $2 \mathrm{~mL}$ of water 15 min before polymerization.

Table 2. Suspension Polymerization and Emulsion Polymerization with Prepolymerization ${ }^{a}$ of Butadiene

\begin{tabular}{|c|c|c|c|c|c|c|c|}
\hline no. & complex $(\mu \mathrm{mol})$ & $\mathrm{BD}[\mathrm{g}]$ & aqueous phase & $\mathrm{PBD}^{b}[\mathrm{~g}]($ yield $\%)$ & TON [mol(BD)/mol(Ni)] & $\begin{array}{l}M_{\mathrm{n}}\left(M_{\mathrm{w}} / M_{\mathrm{n}}\right)^{c} \\
{\left[10^{3} \mathrm{~g} \mathrm{~mol}^{-1}\right]}\end{array}$ & vinyl $/$ trans/cis ${ }^{d}$ \\
\hline $2-1$ & $\mathbf{1}(20)$ & $2.5+23$ & water & $17.5(69)$ & $1.6 \times 10^{4}$ & $23(3.2)$ & $3 / 5 / 92$ \\
\hline $2-2$ & $2(20)$ & $2.9+25$ & water & $18.2(65)$ & $1.7 \times 10^{4}$ & $24(2.8)$ & $4 / 6 / 90$ \\
\hline $2-4$ & $1(20)$ & $2.2+11$ & water/SDS/sonication & $0.6(5)$ & $5.6 \times 10^{2}$ & n.d. & n.d. \\
\hline
\end{tabular}

${ }^{a}$ Reaction conditions and procedure: 1 or $\mathbf{2}$, respectively, dissolved in $0.5 \mathrm{~mL}$ of methylene chloride and $5 \mathrm{~mL}$ of toluene $(1 \mathrm{~mL}$ of methylene chloride and $20 \mathrm{~mL}$ of toluene for entry 3 and 4), prepolymerization at $20^{\circ} \mathrm{C}$ with small amount of butadiene for 4 min, then addition of $100 \mathrm{~mL}$ of water, or 120 $\mathrm{mL}$ of water and $0.9 \mathrm{~g} \mathrm{SDS}$, respectively, and large amount of butadiene under stirring, $1 \mathrm{~min}$ of sonication where applicable (entry 2-4), suspension or emulsion polymerization for $1 \mathrm{~h}$ (entries $2-1,2-2$ ) or $4 \mathrm{~h}$ (entries $2-3,2-4$ ), respectively, at $20^{\circ} \mathrm{C} .{ }^{b}$ Isolated by precipitation with methanol. ${ }^{c}$ Determined by GPC vs PS standards. ${ }^{d}$ Determined by IR.

$\mathrm{mol}^{-1}$ are obtained. A subtle balance of the solubility of the catalyst precursor during the different stages of the polymerization is required in order to obtain colloidally stable polymer dispersions. A predominant insolubility during the dispersing step is believed to prevent decomposition of the catalyst precursor and/or polymerization-active species, subsequent gradual complete dissolution by formation of the polymerizationactive $\mathrm{Ni}$ - polymeryl species is thought to occur. By contrast to polymerization in the absence of water, or polymerization in aqueous suspension, in the highly disperse emulsion system incorporation of butadiene occurs in a 1,4-trans fashion predominantly. This is likely due to coordination of water as a ligand in the active species. This provides access to dispersions of semicrystalline polybutadiene with a low vinyl content of ca. $5 \%$.

\section{Experimental Section}

General Considerations. All syntheses and the handling of $\mathrm{Ni}$ (II) complex solutions were carried out under inert gas atmosphere using standard Schlenk and glovebox techniques. Toluene and diethyl ether were distilled from sodium, methylene chloride from $\mathrm{CaH}_{2}$ under argon. Pentane was passed through columns with molecular sieves and copper catalyst (BASF R 3-11). Demineralized water was degassed by distillation under a steady flow of nitrogen. 
Table 3. Emulsion Polymerization ${ }^{a}$ without Prepolymerization of Butadiene with 2 and 3

\begin{tabular}{|c|c|c|c|c|c|c|c|c|c|}
\hline no. & complex $(\mu \mathrm{mol})$ & amount of toluene & time $[\mathrm{h}]$ & $\mathrm{BD}[\mathrm{g}]$ & $\begin{array}{l}\operatorname{PDB}^{b}[\mathrm{~g}] \\
\text { (yield [\%]) }\end{array}$ & TON $[\mathrm{mol}(\mathrm{BD}) / \mathrm{mol}(\mathrm{Ni})]$ & $\begin{array}{c}M_{\mathrm{n}}\left(M_{\mathrm{w}} / M_{\mathrm{n}}\right)^{c} \\
{\left[10^{3} \mathrm{~g} \mathrm{~mol}^{-1}\right]}\end{array}$ & vinyl/trans/cis ${ }^{d}$ & $T_{\mathrm{tr}}, T_{\mathrm{m}}$ \\
\hline $3-1$ & $2(50)$ & $2 \mathrm{~mL}+2 \mathrm{~mL}$ of $\mathrm{CH}_{2} \mathrm{Cl}_{2}$ & 24 & 13 & $-(0)$ & n.a. & n.a. & n.a. & n.a. \\
\hline $3-2$ & $2(50)$ & $4 \mathrm{~mL}$ & 24 & 15 & $2.3(15)$ & $8.5 \times 10^{2}$ & $25(2.6)$ & $7 / 83 / 10$ & 48,78 \\
\hline $3-3$ & $2(50)$ & $4 \mathrm{~mL}$ & 0.5 & 12 & $1.5(13)$ & $5.6 \times 10^{2}$ & $9.6(3.1)$ & $8 / 71 / 21$ & overlap \\
\hline $3-4$ & $2(150)$ & $12 \mathrm{~mL}$ & 4 & 26 & $12.5(48)$ & $1.5 \times 10^{3}$ & $31(3.1)$ & $4 / 73 / 23$ & 47,69 \\
\hline $3-5$ & $2(300)$ & $12 \mathrm{~mL}$ & 4 & 15 & $15.0(100)$ & $9.3 \times 10^{2}$ & $23(7.9)$ & $5 / 78 / 17$ & 48,74 \\
\hline $3-6$ & $2(300)$ & $12 \mathrm{~mL}$ & 4 & 27 & $22.6(84)$ & $1.4 \times 10^{3}$ & $34(4.7)$ & $4 / 78 / 18$ & 49,77 \\
\hline $3-7$ & $2(150)$ & $12 \mathrm{~mL}$ & 4 & $9.4+13$ & $12.5(56)$ & $1.5 \times 10^{3}$ & $30(3.4)$ & $4 / 78 / 18$ & 48,73 \\
\hline $3-8$ & $3(50)$ & $4 \mathrm{~mL}$ & 4 & 12 & traces & n.a. & n.a. & n.a. & n.a. \\
\hline $3-9$ & $3(100)$ & $4 \mathrm{~mL}$ & 24 & 16 & $1.2(8)$ & $2.2 \times 10^{2}$ & $14(3.3)$ & $7 / 81 / 12$ & 52,83 \\
\hline
\end{tabular}

${ }^{a}$ reaction conditions and procedure for entries 3-1 to 3-3: 2 dissolved (for entry 3-1)/dispersed (for entry 3-2, 3-3) in the organic solvent and 0.2 $\mathrm{mL}$ hexadecane, addition of $0.9 \mathrm{~g}$ SDS in $120 \mathrm{~mL}$ water and butadiene, 2 min ultrasonication, $25^{\circ} \mathrm{C}$. Reaction conditions for entries $3-4$ to $3-9$ : 2 , respectively 3 , dispersed in toluene and $0.6 \mathrm{~mL}$ hexadecane, addition of $2.25 \mathrm{~g}$ SDS in $300 \mathrm{~mL}$ water and butadiene, 2 min US, $25{ }^{\circ} \mathrm{C}$. Entry $3-7$ : further addition of butadiene after $30 \mathrm{~min} .{ }^{b}$ isolated by precipitation with methanol. ${ }^{c}$ determined by GPC vs polystyrene standards. ${ }^{d}$ determined by IR.

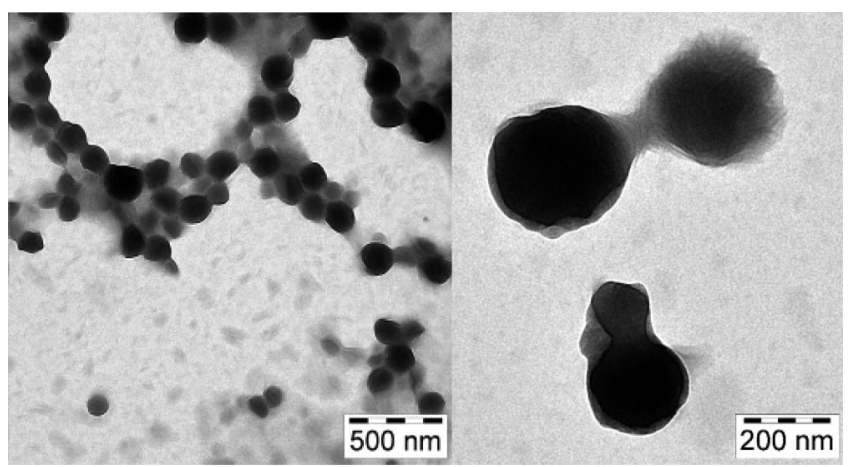

Figure 4. TEM images of 1,4-trans-polybutadiene particles prepared in emulsion (entry 3-6).

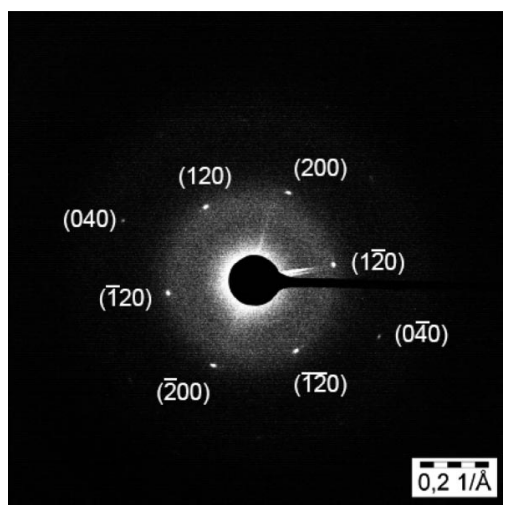

Figure 5. Electron diffraction pattern of a monoclinic 1,4-transpolybutadiene particle prepared via emulsion polymerization (entry $3-6)$.

Hexadecane was degassed via several freeze-pump-thaw-cycles. Butadiene 2.5 was purchased form Air Liquide. NMR spectra were obtained with a Varian Unity INOVA 400 or with a Bruker Avance DRX 600 spectrometer, ${ }^{1} \mathrm{H}$ and ${ }^{13} \mathrm{C}$ NMR chemical shifts were referred to the solvent signal. DLS was performed on a Malvern instrument with $173^{\circ}$ back scattering. DSC was carried out on a Netzsch F1 at a heating/cooling rate of $10 \mathrm{~K} / \mathrm{min}$ on approximately $5 \mathrm{mg}$ of polymer $\left(T_{\mathrm{g}}, T_{\mathrm{tr}}\right.$, and $T_{\mathrm{m}}$ given are from the second heating curves). GPC analyses were performed with a Polymer-Laboratories GPC50 instrument with refractive index detection equipped with two Mixed $\mathrm{C}$ columns in THF at $50{ }^{\circ} \mathrm{C}$ against polystyrene standards. IR spectra of the pure polymer were recorded on a PerkinElmer Spectrum 100 with an ATR sampling accessory; quantitative analyses were calculated according to. ${ }^{19}$ TEM was carried out on a Zeiss Libra 120 instrument operated at $120 \mathrm{kV}$ acceleration voltage. Electron diffraction patterns were recorded at $-64^{\circ} \mathrm{C}$ using a Gatan low temperature sample holder. 1 was prepared according to a reported procedure. ${ }^{9}\left[\left\{\left(\eta^{3}-\mathrm{C}_{3} \mathrm{H}_{5}\right) \mathrm{Ni}(\mu-\mathrm{Cl})\right\}_{2}\right]$ was obtained from
MCAT, Konstanz, Germany, $\mathrm{Li}\left[\mathrm{Al}\left(\mathrm{OC}\left(\mathrm{CF}_{3}\right)_{3}\right)_{4}\right]$ from IoLiTec Ionic Liquids Technologies, Denzlingen, Germany.

Synthesis of 2. In a Schlenk flask $108 \mathrm{mg}(0.4 \mathrm{mmol})$ of [ $\left\{\left(\eta^{3}-\right.\right.$ $\left.\left.\left.\mathrm{C}_{3} \mathrm{H}_{5}\right) \mathrm{Ni}(\mu-\mathrm{Cl})\right\}_{2}\right], 572 \mathrm{mg}(1.62 \mathrm{mmol})$ triphenylantimony and 718 $\mathrm{mg}(0.81 \mathrm{mmol})$ of $\mathrm{Na}\left[\mathrm{B}\left(3,5-\left(\mathrm{CF}_{3}\right)_{2} \mathrm{C}_{6} \mathrm{H}_{3}\right)_{4}\right]^{20}$ were combined. A $10 \mathrm{~mL}$ aliquot of cold diethyl ether was added at $-60{ }^{\circ} \mathrm{C}$, and the dark red solution was stirred for $2 \mathrm{~h}$ while slowly warming to room temperature. The solvent was removed under vacuum. The residue was dissolved in $10 \mathrm{~mL}$ of dichloromethane, and filtered over a pad of celite. The solvent was removed in vacuum and the residual solid was washed twice with $10 \mathrm{~mL}$ of pentane. The product is obtained as a brown powder in $91 \%$ yield $(1.21 \mathrm{~g})$. Yellow to red crystals can be obtained from a diethyl ether solution by addition of pentane.

${ }^{1} \mathrm{H}$ NMR $\left(\mathrm{CD}_{2} \mathrm{Cl}_{2}, 25{ }^{\circ} \mathrm{C}, 400 \mathrm{MHz}\right): \delta 2.96\left(\mathrm{~d}, 2 \mathrm{H}, \mathrm{H}_{\mathrm{anti}},{ }^{3} \mathrm{~J}=\right.$ $14 \mathrm{~Hz}), 4.57\left(\mathrm{~d}, 2 \mathrm{H}, \mathrm{H}_{\mathrm{syn}},{ }^{3} \mathrm{~J}=7 \mathrm{~Hz}\right), 5.60\left(\mathrm{tt}, 1 \mathrm{H}, \mathrm{H}_{\text {central }},{ }^{3} \mathrm{~J}=\right.$ $\left.14 \mathrm{~Hz},{ }^{3} J=7 \mathrm{~Hz}\right), 7.17(\mathrm{~m}, 12 \mathrm{H}), 7.29(\mathrm{~m}, 12 \mathrm{H}), 7.44(\mathrm{~m}, 6 \mathrm{H})$, $7.56\left(\mathrm{~s}, 4 \mathrm{H}, \mathrm{BAr}^{\mathrm{F}}\right), 7.73\left(\mathrm{~s}, 8 \mathrm{H}, \mathrm{BAr}^{\mathrm{F}}\right)$.

${ }^{13} \mathrm{C} \mathrm{NMR}\left(\mathrm{CD}_{2} \mathrm{Cl}_{2}, 25{ }^{\circ} \mathrm{C}, 151 \mathrm{MHz}\right): \delta 162.4\left(\mathrm{q}, \mathrm{BAr}^{\mathrm{F}},{ }^{1} J_{\mathrm{CB}}=\right.$ $50 \mathrm{~Hz}), 135.9\left(\mathrm{C}_{\text {arom }}\right), 135.4\left(\mathrm{BAr}^{\mathrm{F}}\right), 131.5\left(\mathrm{C}_{\text {arom }}\right), 130.6\left(\mathrm{C}_{\text {arom }}\right)$, $130.5\left(\mathrm{C}_{\text {arom }}\right), 129.5\left(\mathrm{q}, \mathrm{CF}_{3},{ }^{2} J_{C F}=32 \mathrm{~Hz}\right), 125.4\left(\mathrm{q}, \mathrm{BAr}^{\mathrm{F}},{ }^{1} J_{C F}\right.$ $=273 \mathrm{~Hz}), 118.1\left(\mathrm{~m},{ }^{4} J_{C F}=4 \mathrm{~Hz}, \mathrm{BAr}{ }^{\mathrm{F}}\right), 107.3\left(\mathrm{C}_{\text {allyl }}\right), 63.7\left(\mathrm{C}_{\text {allyl }}\right)$.

Anal. Calcd for $\mathrm{C}_{71} \mathrm{H}_{47} \mathrm{BF}_{24} \mathrm{NiSb}_{2}$ : C, 51.09; H, 2.84. Found: $\mathrm{C}$, 51.18; H, 2.90.

Synthesis of 3. In a Schlenk flask $67.6 \mathrm{mg}(0.25 \mathrm{mmol})$ of [ $\left\{\left(\eta^{3}-\right.\right.$ $\left.\left.\left.\mathrm{C}_{3} \mathrm{H}_{5}\right) \mathrm{Ni}(\mu-\mathrm{Cl})\right\}_{2}\right], 353.1 \mathrm{mg}(1.00 \mathrm{mmol})$ triphenylantimony and $487.0 \mathrm{mg}(0.50 \mathrm{mmol})$ of $\mathrm{Li}\left[\mathrm{Al}\left(\mathrm{OC}\left(\mathrm{CF}_{3}\right)_{3}\right)_{4}\right]$ were combined. Cold diethyl ether $(20 \mathrm{~mL})$ was added at $-60{ }^{\circ} \mathrm{C}$, and the dark red solution was stirred for $4 \mathrm{~h}$ while slowly warming to room temperature. The solvent was removed under vacuum. The residue was dissolved in $10 \mathrm{~mL}$ of dichloromethane, and filtered over a pad of celite. The solvent was reduced in vacuum to approximately $3 \mathrm{~mL}$ and layered with $30 \mathrm{~mL}$ of pentane. The desired complex slowly crystallized overnight at $-30{ }^{\circ} \mathrm{C}$, the supernatant solvent was removed and the crystals were washed three times with pentane and dried in vacuum. The product is obtained as red to yellow crystals in $80 \%$ yield (709 $\mathrm{mg}$ ).

${ }^{1} \mathrm{H} \mathrm{NMR}\left(\mathrm{CD}_{2} \mathrm{Cl}_{2}, 25{ }^{\circ} \mathrm{C}, 400 \mathrm{MHz}\right): \delta 2.96\left(\mathrm{~d}, 2 \mathrm{H}, \mathrm{H}_{\text {antit }},{ }^{3} \mathrm{~J}=\right.$ $14 \mathrm{~Hz}), 4.47\left(\mathrm{~d}, 2 \mathrm{H}, \mathrm{H}_{\mathrm{syn}},{ }^{3} \mathrm{~J}=7 \mathrm{~Hz}\right), 5.62\left(\mathrm{tt}, 1 \mathrm{H}, \mathrm{H}_{\text {central }},{ }^{3} \mathrm{~J}=\right.$ $\left.14 \mathrm{~Hz},{ }^{3} \mathrm{~J}=7 \mathrm{~Hz}\right), 7.17(\mathrm{~m}, 12 \mathrm{H}), 7.29(\mathrm{~m}, 12 \mathrm{H}), 7.45(\mathrm{~m}, 6 \mathrm{H})$.

${ }^{19} \mathrm{~F}$ NMR $\left(\mathrm{CD}_{2} \mathrm{Cl}_{2}, 25{ }^{\circ} \mathrm{C}, 188 \mathrm{MHz}\right): \delta-76\left(\mathrm{~s}, \mathrm{CF}_{3}\right)$.

${ }^{13} \mathrm{C}$ NMR $\left(\mathrm{CD}_{2} \mathrm{Cl}_{2}, 25{ }^{\circ} \mathrm{C}, 151 \mathrm{MHz}\right): \delta 135.9\left(\mathrm{C}_{\text {arom }}\right), 131.7$ $\left(\mathrm{C}_{\text {arom }}\right), 130.6\left(\mathrm{C}_{\text {arom }}\right), 130.1\left(\mathrm{C}_{\text {arom }}\right), 121.9\left(\mathrm{q}, \mathrm{Al}\left(\mathrm{OC}\left(C \mathrm{~F}_{3}\right)\right)_{4},{ }^{1} J_{C F}\right.$ $=293 \mathrm{~Hz}), 109.8\left(\mathrm{C}_{\text {allyl }}\right), 79.6\left(\mathrm{~b}, \mathrm{Al}\left(\mathrm{OC}\left(\mathrm{CF}_{3}\right)\right)_{4}\right), 65.2\left(\mathrm{C}_{\text {allyl }}\right)$.

$\mathrm{X}$-ray Crystal Structure Determination of 3. The data collection was performed at $100 \mathrm{~K}$ on a STOE IPDS-II diffractometer equipped with a graphite-monochromated radiation source $(\lambda=$ $0.71073 \AA$ A) and an image plate detection system. A crystal mounted on a fine glass fiber with silicon grease was employed. The selection, integration, and averaging procedure of the measured reflex intensities, the determination of the unit cell dimensions by a least-squares fit of the $2 \theta$ values, data reduction, LP correction, and space group determination were performed using the X-Area software package delivered with the diffractometer. A semiempirical 
absorption correction was not performed. The structure was solved by direct methods (SHELXS-97), completed with difference Fourier syntheses, and refined with full-matrix least-squares using SHELXL97 minimizing $w\left(F_{\mathrm{o}}{ }^{2}-F_{\mathrm{c}}{ }^{2}\right)^{2}$. Weighted $R$ factor $(w R)$ and the goodness of fit $S$ are based on $F^{2}$; the conventional $R$ factor $(R)$ is based on $F$. All non-hydrogen atoms were refined with anisotropic displacement parameters. All scattering factors and anomalous dispersion factors are provided by the SHELXL-97 program. The hydrogen atom positions were calculated geometrically and were allowed to ride on their parent carbon atoms with fixed isotropic $U_{11}=0.02$.

Polymerizations. Polymerizations were carried out in a $500 \mathrm{~mL}$ glass pressure reactor equipped with a mechanical stirrer (500 rpm) and with a cooling/heating jacket supplied by a thermostat controlled by a thermocouple dipping into the polymerization mixture. Optionally, the two phase system was homogenized by means of an ultrasound sonotrode mounted in the reactor (operated at 120 $\mathrm{W}, 2 \mathrm{~min})$.

For solution polymerization complex 1, 2, or $\mathbf{3}$ was dissolved in the respective solvent or solvent plus water, the solution was cannula transferred into the reactor and butadiene was added.

For suspension polymerization $20 \mu \mathrm{mol}$ of the respective complex were dissolved in a mixture of $0.5 \mathrm{~mL}$ of methylene chloride and $4 \mathrm{~mL}$ of toluene, and cannula transferred into the reactor at $20^{\circ} \mathrm{C}$. A small fraction of butadiene was added and the prepolymerization was allowed to continue for 4 min under stirring with a magnetic stirring bar. Then water $(100 \mathrm{~mL})$ was pumped in under stirring with the mechanical stirrer (500 rpm), and further butadiene was added. The polymerization was allowed to continue for an hour.

For emulsion polymerization SDS was dissolved in water and complex $\mathbf{2}$ or $\mathbf{3}$ were separately dissolved/dispersed in the respective organic solvent mixture. The surfactant and the catalyst solution/ dispersion were cannula transferred into the reactor at $20{ }^{\circ} \mathrm{C}$. Butadiene was added under stirring $(500 \mathrm{rpm})$ and sonication was immediately applied for $2 \mathrm{~min}$. The temperature was set to $25^{\circ} \mathrm{C}$.

All polymerization experiments were stopped by releasing the residual pressure, applying vacuum several times, and exposing to air. For analysis of the bulk properties the polymer solution or latex was poured into methanol containing BHT as a stabilizer. The supernatant solvents were decanted or filtered off, and the polymer was washed with methanol and dried overnight at $50{ }^{\circ} \mathrm{C}$ under vacuum.

For TEM analysis one drop of the diluted dispersion was deposited on a carbon-coated 400 mesh copper grid and allowed to dry at room temperature.

Acknowledgment. Financial support by BASF SE is gratefully acknowledged. The authors thank Hans-Helmut Görtz, Valentine Reimer and Tobias Steinke of BASF SE for fruitful discussions. We thank Lars Bolk for GPC analyses, and Marina Krumova for TEM studies. S.M. is indebted to the Fonds der Chemischen Industrie.

Supporting Information Available: A figure showing the IR spectra of selected polybutadiene samples and a CIF file for $\mathbf{3}$. This material is available free of charge via the Internet at http:// pubs.acs.org.

\section{References and Notes}

(1) (a) Urban, D.; Takamura, K. Polymer dispersions and their industrial applications; Wiley-VCH: Weinheim, Germany, 2002. (b) van Herk,
A. M. Chemistry and Technology of Emulsion Polymerisation; Blackwell Publishing: Oxford, U.K. 2005. (c) Distler, D. Wässrige Polymerdispersionen; VCH: Weinheim, Germany, 1999. (d) Fitch, R. M. Polymer Colloids; Academic Press: San Diego, CA, 1997. (e) Lovell, P. A.; El-Aasser, M. S. Emulsion Polymerization and Emulsion Polymers; Wiley: Chichester, U.K., 1997.

(2) Obrecht, W. In Ullmann's Encyclopedia of Industrial Chemistry; 6th ed.; Wiley-VCH: Weinheim, Germany, 2003; Vol. 31, pp 461-600.

(3) Rinehart, R. E.; Smith, H. P.; Witt, H. S.; Romeyn, H. J. Am. Chem. Soc. 1961, 83, 4864-4865.

(4) (a) Allegra, G.; Lo Giudice, F.; Natta, G.; Giannini, U.; Fagherazzi, G.; Pino, P. Chem. Commun. 1967, 1263-1265. (b) Crewdson, P.; Bryce, D. L.; Rominger, F.; Hofmann, P. Angew. Chem., Int. Ed. 2008, 47, 3454-3457.

(5) (a) Monteil, V.; Bastero, A.; Mecking, S. Macromolecules 2005, 38, 5393-5399. (b) Monteil, V.; Wehrmann, P.; Mecking, S. J. Am. Chem. Soc. 2005, 127, 14568-14569. (c) Henderson, J. N.; Donbar, K. W.; Barbour, J. B.; Bell, A. (Goodyear) US 4,429,085, 1984. (d) Burroway, G. L. (Goodyear) US 5,278,263, 1994. (e) Bell, A. J. (Goodyear) EP $0475221,1995$.

(6) (a) Claverie, J. P.; Viala, S.; Maurel, V.; Novat, C. Macromolecules 2001, 34, 382-388. (b) Chemtob, A.; Heroguez, V.; Gnanou, Y. Macromolecules 2004, 37, 7619-7627.

(7) Taube, R.; Sylvester, G. In Applied Homogeneous Catalysis with Organometallic Compounds; 1st ed.; Cornils, B., Hermann, W. A., Eds.; Wiley-VCH: Weinheim, Germany, 2000; pp 280-318, and literature therein.

(8) (a) Mecking, S. Colloid Polym. Sci. 2007, 285, 605-619. (b) Claverie, J. P.; Soula, R. Prog. Polym. Sci. 2003, 28, 619. (c) Mecking, S.; Held, A.; Bauers, F. M. Angew. Chem., Int. Ed. 2002, 41, 544-561.

(9) Cámpora, J.; Conejo, M d M.; Reyes, M. L.; Mereiter, K.; Passaglia, E. Chem. Commun. 2003, 78-79.

(10) (a) Krossing, I.; Raabe, I. Angew. Chem. 2004, 116, 2116-2142; Krossing, I.; Raabe, I. Angew. Chem., Int. Ed. 2004, 43, 2066-2090. (b) Krossing, I. Chemistry 2001, 7, 490-502.

(11) (a) Taube, R.; Gehrke, J.-P.; Schmidt, U. J. Organomet. Chem. 1985, 292, 287-296. (b) Taube, R.; Gehrke, J.-P. J. Organomet. Chem. 1987, 328, 393-401.

(12) For crystal structures of complexes of the type $\left[\left(\eta^{3}-\mathrm{C}_{3} \mathrm{H}_{5}\right) \mathrm{NiL}_{2}\right] \mathrm{A}$ (with $\mathrm{L}=$ monodentate ligand and $\mathrm{A}=$ anion) $\mathrm{cf}$. (a) Sirigu, A. Inorg. Chem. 1970, 9, 2245-2249. (b) Alberti, D.; Goddard, R.; Rufinska, A.; Porschke, K. R. Organometallics 2003, 22, 4025-4029. (c) Gareau, D.; Sui-Seng, C.; Groux, L. F.; Brisse, F.; Zargarian, D. Organometallics 2005, 24, 4003-4013. (d) O'Connor, A. R.; White, P. S.; Brookhart, M. J. Am. Chem. Soc. 2007, 129, 4142-4143.

(13) Intermittently signals of a new allylic system are observed: ${ }^{1} \mathrm{H}$ NMR $\left(\mathrm{CD}_{2} \mathrm{Cl}_{2}, 25^{\circ} \mathrm{C}, 400 \mathrm{MHz}\right): \delta 5.88$ (tt, $\left.J=13 \mathrm{~Hz}, J=6 \mathrm{~Hz}\right), 3.04$ (d, $J=6 \mathrm{~Hz}), 2.04(\mathrm{~d}, J=13 \mathrm{~Hz})$. It is speculated that these signals arise from a complex in which water acts as a coordinating ligand.

(14) (a) Englin, B. A.; Plate, A. F.; Tugolukov, V. M.; Pryanishnikova, M. A. Chem. Technol. Fuels Oils 1965, 1, 722. (b) Rossberg, M. In Ullmann's Encyclopedia of Industrial Chemistry; 6th ed.; Wiley-VCH: Weinheim, Germany, 2003; Vol. 8, pp 4-7.

(15) Mecking, S.; Monteil, V.; Huber, J.; Kolb, L.; Wehrmann, P. Macromol. Symp. 2006, 236, 117-123.

(16) (a) Iwayanagi, S.; Sakurai, I.; Sakurai, T.; Seto, T. J. Macromol. Sci.-Phys. 1968, 2, 163-177. (b) Suehiro, K.; Takayanagi, M. J. Macromol. Sci.-Phys. 1970, 4, 39-46.

(17) Finter, J.; Wegner, G. Makromol. Chem. 1981, 182, 1859-1874.

(18) Yang, X.; Cai, J.; Kong, X.; Dong, W.; Li, G.; Zhou, E. Macromol. Chem. Phys. 2001, 202, 1166-1172.

(19) Morero, D.; Santambrogio, A.; Porri, L.; Ciampelli, F. Chim. Ind. 1959, $41,758-762$. For analysis of polybutadienes using ATR-IR cf. Shimadzu Application News No. A321.

(20) (a) Reger, D. L.; Little, C. A.; Lamba, J. J. S.; Brown, K. J. Inorg. Synth. 2004, 34, 5-8. (b) Brookhart, M.; Grant, B.; Volpe, A. F. Organometallics 1992, 11, 3920-3922. 